\title{
The Role of Education in the Formation of Tax Ethics in Azerbaijan
}

\author{
Mubariz Mammadli ${ }^{1}$ \\ ${ }^{1}$ Assoc. Prof., Azerbaijan State University of Economics, UNEC Business School, Department of \\ Economics and Business Management
}

Email:mubariz.mammadli@unec.edu.az

\section{Zivar Zeynalova ${ }^{2}$}

${ }^{2}$ Lecturer, PhD., Academy of Public Administration under the President of the Republic of Azerbaijan, Faculty of Public Administration, Department of Legal Regulation of Economy;

Email: zivarzz@mail.ru

Article History: Received: 10 November 2020; Revised 12 January 2021 Accepted: 27 January 2021; Published online: 5 April 2021

\begin{abstract}
This paper discusses the importance of tax ethics, as well as the impact of education on it. The impact of tax-oriented education on tax ethics was determined in the case of Azerbaijan. For this purpose, it was applied a questionnaire survey to 250 students studied at the Academy of Public Administration under the President of the Republic of Azerbaijan between 2017 and 2019 years. The collected data were analyzed descriptively, and the hypothesis was tested using the Paired Samples Test. Cronbach's Alpha conducted to verify the validity of the research. Analyzes and tests were carried out electronically using the SPSS 16.0 software. As a result of empirical research, it turned out that the attitude towards taxation was higher after passing tax classes.
\end{abstract}

Keywords: Tax ethics, Taxation education, Tax attitude, Empirical study, Azerbaijan.

\section{Introduction}

The taxpayer's own consent and willingness to pay taxes, rather than the coercive power of the state, is one of the important factors in the economic and social sustainability of the state in the process of tax collection (Kalendiene and Pukeliene, 2011). There are too many variables that affect the collection of taxes in full. One of these variables is the tax attitude of taxpayers and their behavior towards tax. Tax perceptions and taxpayer attitudes towards taxation are formed in the process of social interaction and are passed on from generation to generation (Murphy, 2005).

State always wants to minimize the negative perception and behavior of taxpayers in relation to taxation and to ensure that they pay taxes with their own consent on time (Alm and Torgler, 2006). Providing proper tax returns by taxpayers and paying taxes on time is called "tax compliance" (James and Alley, 2002). The level of tax compliance in society is actually associated with the existing of tax ethics of citizens. Since non-compliance behavior among taxpayers can sometimes be a reflection of a low level of tax ethics (Torgler, 2006). In order 
to increase tax ethics, each state can implement various regulatory or control measures. However, the success achieved with a particular method in one government may not have the same effect in another state. Therefore, in the literature, tax ethics and the factors affecting it may vary and the methods used to improve it may be different. In the literature, one of the widely discussed factors affecting tax ethics is education. Traditionally, education can be expressed in the form of actions and efforts aimed at achieving positive attitudes and behavior towards people and society. There is always a need for training programs that help to raise awareness of taxes and increase tax ethics, especially in societies with low tax compliance, to ensure a positive attitude of taxpayers towards taxes. Training taxpayers in financial matters can contribute to the positive development of tax behavior, contributing to tax compliance (Carley and Maxwell, 2006).

In general, education has two opposing functions, both to preserve and maintain cultural values, and to make changes (Ottoway, 1962). In order to ensure the optimal occurrence of these two conflict situations, the government should organize effective training in tax ethics. In order to increase tax ethics, training programs should be conducted to protect the positive cultural values of taxpayers and decrease negative attitudes and behavior.

Considering the importance of education in tax ethics, the main question of the study is: "Does education affect tax ethics in Azerbaijan?". Determining the correct answer to this question may contribute to shaping the state regulations and increasing the efficiency of taxation in the country. Based on the main question, we test the following hypothesis.

$\mathrm{H}$ - Tax-oriented education does not have a significant impact on tax attitudes.

The survey will show us whether the hypothesis of the study is true or not, and we will be able to determine the effect of education on tax ethics in Azerbaijan. In this context, first of all, tax ethics and the factors that influence it are considered, and studies examining the impact of education on tax ethics are analyzed. To assess the impact of education on tax ethics and to prove the research hypothesis in the last section of the study paper the survey results of 250 people among students were given. Since the influence of education on tax ethics in Azerbaijan has not been empirically investigated, this study will make a great contribution to the field.

\section{Literature Review}

Foundation studies on tax ethics was laid in the 1960s by the Cologne School of Tax Psychology, founded by German scientists under the leadership of Schmölders. The members of this school tried to connect economics and social psychology, and considered tax ethics as voluntary compliance behavior (Alm and Torgler, 2006). Schmölders defines tax ethics as the timely and complete discharge of duties and obligations related to taxation (Torgler, 2003).

Tax ethics is defined by many researchers as an intrinsic motivation to pay taxes. Here, tax ethics is intrinsically motivated without external pressure. Accordingly, it is assumed that people will either pay the tax voluntarily or not pay it, given the risk of being caught and punished (Doerrenberg and Peichl, 2017). Various factors affecting tax ethics are shown in 
the literature. Even if these factors are very broad, some of them can be systematized as follows (Alm et al., 2012; Besley and Persson, 2014; Chen, 2019; Fanea-Ivanovici et al., 2019; Kot et. al., 2019; McGee, 1999):

- sense of justice of taxpayers,

- social status of taxpayers,

- religious beliefs of taxpayers,

- simplicity and clarity of the tax system,

- justice in the tax system,

- believing in the necessity and transparency of government spending,

- democracy,

- quality of public services,

- the level of education of taxpayers.

All the above factors are important for establishing moral values forming attitudes towards tax ethics and indicate the need to regulate (if possible) these factors in order to collect the necessary tax revenues. As can be seen from the above list, education is one of the most important factors in the designing of a tax-compliant society. Extensive research is being conducted in both developing and developed countries on this subject and the direction of the relationship between education and tax ethics is tried to be determined.

Despite, Eriksen and Fallan (1996) mentioned that there may be people with a low level of education who have a high knowledge about taxation; one group scholars mentioned that there is a positive relationship between education level of taxpayers and tax ethics (Torgler et.al., 2008; Lin and Carrol, 2000; Alm, 1992). In other words, as the level of education increases, the understanding ability to tax laws rises and compliance with legal changes accelerates. It is argued that such taxpayers are more aware of their obligations (Ipek and Kaynar, 2009; Loo, 2009). In this context, it can be emphasized that educated taxpayers will more consciously assess the benefits and services provided by the state, and, consequently, this will increase their tax compliance (Hashimzade, 2013; Kwok and Yip, 2018). However, some studies have found the opposite and emphasize that a more educated person is no longer willing to pay taxes Beron et.a., 2014; Chan, 2000; Dubin et.al, 1990). The reasons for the differences in the research results are due to some behavioral factors that guide taxpayers' opinions in different directions. McGee (2012) explains these contradictory conclusions in a way that, wealthier taxpayers tend to be more educated than others, and they may be more prone to observing the law. On the other hand, the rich are taxed more than the poor, and paying a huge amount of taxes makes them consider tax evasion a more positive behavior.

Chan et al. (2000) observed a negative correlation between education level and tax compliance by examining 157 student surveys collected from universities in the USA and Hong Kong. Compared to surveys of students from six countries, McGee and Ross (2012) identified the relationship between education and tax compliance. In their studies, the results have changed by country. The most opponents of tax evasion were people with lower educational attainment from Brazil, Russia and China, while those with a highest level of 
educational attainment demonstrate a higher tax ethics in India and the United States. However, in Germany, people with medium level of education exhibited the lowest levels of tax compliance. Preobragenskaya and McGee (2016) did research on demographic study of Russian attitudes towards tax evasion, and found that opposition to tax evasion was less among the higher educated people. In spite of all, Milliron (1985) found no connection between the level of education and tax ethics.

The impact of taxation knowledge directly on tax ethics has been determined by various studies. Extensive research has been conducted in Turkey to assess the impact of tax education on taxpayers' awareness. For example, Sağlam (2013) sought to measure tax perceptions and tax awareness as a determinant of students' attitudes and behavior towards tax. This study was carried out on the last year students of Hittite University in Faculty of Economics and Administrative Sciences. The study showed that the tax perception of students was high. On the other hand, it was stated that if the public is informed about where the collected taxes are spent, the taxpayers' awareness will increase. In 2016, Teyyare and Kumbaşl1 conducted a questionnaire on first- and fourth-year students studying in the finance department of three universities to identify the level of tax awareness and tax ethics, and to determine the impact of taxation education. As a result of the empirical study, it was found that the fourth-year students had higher tax awareness and ethics than the first-year students of the Finance Faculty. Çiçek and Bitlisli (2017) aimed to measure the impact of education on tax awareness of students. The impact of education on tax awareness was assessed by observing the differences between the two groups of students (those with and without tax education). According to the analysis results it was clear that tax attitudes and tax awareness of the students who had education were more positive than the students who did not have education.

Analyzing the impact of education on tax ethics in Azerbaijan, it appears that this issue has not been widely studied. In other words, these questions can be approached only theoretically, without empirical research.

\section{Methodology of Research}

The survey method was applied as part of the study, and third-grade students enrolled in the specialties of Economics, Management and State and Municipal Administration at the Academy of Public Administration under the President of the Republic of Azerbaijan in 2017-2019 were included in the study. 250 students took part in this survey. Students were asked to answer three questions - "What is a tax?", "Would you like to give part of your income to the government as tax?" and "Do you think that citizens who do not pay their taxes are guilty?". In order not to guide students, open-ended questions were used in the questionnaire. Students' own statements were emphasized in the analysis. The study was conducted in two stages. At the first stage, students were asked to answer questions before passing the tax class. At the second stage, the same students again answered the same questions after completing the course 'Taxes and Taxation' for one semester. Thus, students' attitudes towards taxation before and after training was evaluated separately and taken into account for comparisons. Since open questions were used in the questionnaire, after 
collecting the answers, expressions of similar values were combined into one group and Statistics Package for The Social Sciences was used for analysis. The hypothesis was tested using the Paired Samples Test. The reliability of the scales used in the study was measured using the Cronbach's alpha test.

\section{Findings}

Firstly, students were asked to indicate their gender. 122 students from 250 were female and 128 were male.

\section{Question 1}

In order to evaluate the tax perception of students, they were asked to answer the question: "What is a tax?". When the students' responses were studied, it became clear that the concept of taxation has a positive meaning for some students. Some students said that "it is a civil obligation", "it is money that we pay for environmental protection", "it is a fee for public services, especially for the provision of health, education and safety services." The other part of students showed a negative attitude and gave different answers to this concept. These answers are "it is money taken from our income", "it is a heavy burden for a citizen", "it is a debt", "it is a payment that we don't know where it is spent", "it is a mandatory payment, which reduces our well-being" and "it is a burden that I have always thought about how to avoid it". These answers show that some students perceive tax as a negative phenomenon. Thus, the responses received from the students participating in the survey are systematized in Table 1.

Table 1. What is a tax?

\begin{tabular}{|c|c|c|c|}
\hline \multicolumn{4}{|c|}{ Positive approach } \\
\hline & & Before & After \\
\hline & & education & education \\
\hline \multirow[t]{2}{*}{ Citizenship duty } & Frequencies & 22 & 38 \\
\hline & $\%$ & 8.8 & 15.2 \\
\hline Money to protect our & Frequencies & 25 & 23 \\
\hline environment & $\%$ & 10 & 9.2 \\
\hline \multirow[t]{2}{*}{ Public service fee } & Frequencies & 73 & 109 \\
\hline & $\%$ & 29.2 & 43.6 \\
\hline \multicolumn{4}{|c|}{ Negative approach } \\
\hline Money collected from & Frequencies & 75 & 50 \\
\hline $\begin{array}{c}\text { income (money that reduces } \\
\text { our well-being) }\end{array}$ & $\%$ & 30 & 20.0 \\
\hline \multirow[t]{2}{*}{ Heavy burden and debt } & Frequencies & 29 & 19 \\
\hline & $\%$ & 11.6 & 7.6 \\
\hline \multirow[t]{2}{*}{ Unnecessary expense } & Frequencies & 26 & 11 \\
\hline & $\%$ & 10.4 & 4.4 \\
\hline
\end{tabular}

As can be seen from table 1, while the proportion of those who attached a negative value to the tax concept before education was $52.0 \%$, this level decreased after education and was 
$32 \%$. On the contrary, the share of those who had positive approach increased from $48 \%$ to $68 \%$. In other words, there have been marked positive changes in students' attitudes towards taxes after education. Before education, $51.1 \%$ of women gave positive answers about the value of the tax, after education this indicator was $65.6 \%$. Growth rates were higher among men. Namely, $46.3 \%$ of men had a positive attitude before education, while this figure rose to $70.4 \%$ after education.

\section{Hypothesis testing}

To prove the hypothesis of the study we use Paired Samples Test. Using this test, we can find whether the mean values of two metric variables are equal or not, and determine the p-value.

Table 2. The result of Paired Samples Test

\begin{tabular}{|c|c|c|c|c|c|c|c|c|c|}
\hline & \multicolumn{9}{|c|}{ Paired Samples Statistics } \\
\hline \multirow{3}{*}{ Pair 1} & & Mean & $\mathrm{N}$ & \multicolumn{3}{|c|}{ Std. Deviation } & \multicolumn{3}{|c|}{ Std. Error Mean } \\
\hline & $\begin{array}{l}\text { What is a tax? } \\
\text { (before education) }\end{array}$ & 3.57 & 250 & \multicolumn{3}{|c|}{1.355} & \multicolumn{3}{|c|}{.086} \\
\hline & $\begin{array}{l}\text { What is a tax? } \\
\text { (after education) }\end{array}$ & 3.09 & 250 & \multicolumn{3}{|c|}{1.264} & \multicolumn{3}{|c|}{.080} \\
\hline \multicolumn{10}{|c|}{ Paired Samples Correlations } \\
\hline \multirow[b]{2}{*}{ Pair 1} & & \multicolumn{2}{|r|}{$\mathrm{N}$} & \multicolumn{3}{|c|}{ Correlation } & \multicolumn{3}{|c|}{ Sig. } \\
\hline & $\begin{array}{l}\text { What is a tax? } \\
\text { (before education) } \\
\& \text { What is a tax? } \\
\text { (after education) }\end{array}$ & \multicolumn{2}{|r|}{250} & \multicolumn{3}{|c|}{.636} & \multicolumn{3}{|c|}{.000} \\
\hline \multicolumn{10}{|c|}{ Paired Samples Test } \\
\hline \multicolumn{10}{|c|}{ Paired Differences } \\
\hline \multirow[b]{3}{*}{ Pair 1} & & & Std. & $\begin{array}{l}\text { Std. } \\
\text { Error } \\
\text { Mean }\end{array}$ & $\begin{array}{r}95 \\
\text { Confi } \\
\text { Interva } \\
\text { Diffe }\end{array}$ & $\begin{array}{l}\% \\
\text { of the } \\
\text { ence }\end{array}$ & & & $\begin{array}{l}\text { Sig. } \\
(2-\end{array}$ \\
\hline & & Mean & Deviation & & Lower & Upper & $\mathrm{T}$ & df & tailed) \\
\hline & $\begin{array}{l}\text { What is a tax? } \\
\text { (before education) } \\
\text { - What is a tax? } \\
\text { (after education) }\end{array}$ & .480 & 1.120 & .071 & .340 & .620 & 6.776 & 249 & .000 \\
\hline
\end{tabular}

Table 2 points that the p-value is smaller than 0.05 and the "t" value is significant. In other words, there is a statistically significant difference between the mean scores before and after tax education with a probability of $95 \%$. This shows that the research hypothesis is rejected and a relationship does exist between tax education and tax attitude.

\section{Question 2}

The next question asked to students was "Would you like to give part of your income to the government as tax?". The question focuses on examining students' attitudes towards voluntary tax compliance. The responses obtained are systematized in Table 3. 
Table 3. Would you like to give part of your income to the government as tax?

\begin{tabular}{cccc}
\hline & & Before education & After education \\
\hline Yes & Frequencies & 106 & 148 \\
& $\%$ & 42.4 & 59.2 \\
No & Frequencies & 93 & 71 \\
& $\%$ & 37.2 & 28.4 \\
I'm not sure & Frequencies & 51 & 31 \\
& $\%$ & 20.4 & 12.4 \\
\hline
\end{tabular}

According to Table 3, the number of students who answered "no" and "I am not sure" before education was $57.6 \%$. After tax class, this ratio dropped to $40.8 \%$. In addition, there were no students who changed their positive thoughts after learning. $46.7 \%$ of women and $40.0 \%$ of men wanted to give part of their income to the government as a tax before tax class. After education, this figure increased by $56.6 \%$ and $61.7 \%$ respectively.

\section{Question 3}

The last question sought to explore the students' opinion on tax evasion. They were asked to agree or disagree with whether citizens who do not pay taxes are guilty. The answer to this question is shown in table 4.

Table 4. Do you think that citizens who do not pay their taxes are guilty?

\begin{tabular}{cccc}
\hline & & Before education & After education \\
\hline Yes & Frequencies & 88 & 139 \\
& $\%$ & 35.2 & 55.6 \\
No & Frequencies & 118 & 80 \\
& $\%$ & 47.2 & 32.0 \\
\multirow{2}{*}{ I'm not sure } & Frequencies & 44 & 31 \\
& $\%$ & 17.6 & 12.4 \\
\hline
\end{tabular}

Table 4 reveal that the number of students who answered "yes" before education was $35.2 \%$, while after tax class, this ratio increased to $55.6 \%$. The results show that students are becoming tougher against tax evaders. Before education, the distribution of "yes" by sex was $40.0 \%$ and $32.5 \%$, respectively, among women and men. After education, these figures changed and amounted to $54.1 \%$ for women and $57.0 \%$ for men.

Hereby, Independent Samples Test has been applied using the SPSS software package to determine statistical evidence between gender and tax attitudes. Since the probability value of t-statistics was higher than 0.05 , it was determined that there is not statistically significant relationship between tax education and gender.

\section{Cronbach's Alpha test}

At the end of the study, the Cronbach's Alpha test was conducted to verify the validity of this survey. 
Table 5. Cronbach Alpha Coefficient

\begin{tabular}{|c|c|c|c|c|c|c|c|}
\hline \multicolumn{3}{|c|}{$\begin{array}{l}\text { Case Processing } \\
\text { Summary }\end{array}$} & & \multicolumn{2}{|c|}{$\begin{array}{c}\text { Reliability Statistics } \\
\text { (before education) }\end{array}$} & \multicolumn{2}{|c|}{$\begin{array}{l}\text { Reliability Statistics } \\
\text { (after education) }\end{array}$} \\
\hline \multirow{4}{*}{$\begin{array}{c}\text { Case } \\
\mathrm{s}\end{array}$} & & $\mathrm{N}$ & $\%$ & Cronbach's Alpha & $\mathrm{N}$ of Items & $\begin{array}{l}\text { Cronbach's } \\
\text { Alpha }\end{array}$ & $\mathrm{N}$ of Items \\
\hline & Valid & 250 & $\begin{array}{c}100 . \\
0\end{array}$ & .892 & 2 & .952 & 2 \\
\hline & $\begin{array}{c}\text { Exclude } \\
\mathrm{d}^{\mathrm{a}}\end{array}$ & 0 & .0 & & & & \\
\hline & Total & 250 & $\begin{array}{c}100 . \\
0\end{array}$ & & & & \\
\hline
\end{tabular}

According to Cronbach's Alpha, the relationship between categorical variables is significant because it is above 0.7. The alpha value before education is 0.892 , and after education is 0.952 . Thus, a high value of alpha indicates that this survey is very reliable.

\section{Discussion}

As can be seen from the results, taxation education has had a positive impact on students' tax attitudes. This result was similar to the results of the analysis of Teyyare and Kumbaşl (2016) and Çiçek and Bitlisli (2017). Considering that the students will be future taxpayers (even some of them are taxpayers), their attitude towards taxation is very important because it reflects their tax ethics.

As mentioned above, the duration of the tax class was one semester and during these periods students collected a huge amount of information on taxation. Throughout the program, students acquired a solid theoretical base in the field of taxation. Students received information about the basic principles of taxation, especially equity. At the same time, the functions of taxation and their importance were discussed. Students read the materials and discussed the possible positive and negative effects of each function from different angles. In addition, they discussed the main features of a flat tax and a progressive tax, as well as their advantages and disadvantages. Possible impacts on taxpayer behavior were also discussed in the context of tax competition, tax evasion and tax justice. Moreover, while studying the tax system of Azerbaijan - tax code, tax rates, the form and time of collection, the rights and obligations of tax authorities and taxpayers, as well as the implemented reforms for effective tax administration; Students received general information about the tax systems of foreign countries. The share of income tax, consumption tax and property tax in the total amount of tax revenues and their rates were discussed for different countries. Social expenditures of these countries were also analyzed for international comparison using data from the OECD, Word Bank and official websites of tax authorities.

Information about foreign countries was collected by a group of students as a subject of research paper. They could choose foreign tax systems that interested them. But they had to choose at least one developed country, one developing country, and one Islamic country. After analyzing different countries in different classes, students studied the tax systems of the 
USA, Canada, Norway, Sweden, Turkey, Russia, Germany, Italy, China, Japan, Australia, Saudi Arabia and Iran. At the same time, reading various articles on tax ethics, tax evasion and tax avoidance, students get acquainted with the main factors that influence these issues, as well as the impact of these issues on the economy and society.

In the light of the tax information received, the attitude of students towards taxation has changed significantly. The students were asked about the reason for the change. Students who would like to give part of their income as a tax generally said that "we understood the functions and significance of taxes for whole society." Those students who did not change their opinion and answered "no" and "I am not sure" generally said that "I would like to manage my money myself" and "budget transparency is not satisfactory". After education, the total percentage of these students, who said they did not want to give their income as a tax, and they were not sure about this case, accounted for 40.8 percent. The majority of these students mentioned that they did not believe budget transparency. To summarize, some of the students' answers were as follows.

If I hide my income, I cannot get a bank loan when I need it. Therefore, I must correctly record my earnings. (Student 1)

I am a person who is against the tax. If everyone fulfills the citizenship (social) responsibility properly, there is no need to collect money through taxes. (Student 2)

I personally would agree if I knew that the tax is used for the right purposes. As a brief example, I think it is enough to show people working in government bodies or tax authorities who drive cars worth hundreds of thousands of manats with low salaries. (Student 3)

The government is already implementing the necessary tax expenditures. I cannot understand those who hide their income and do not pay taxes. (Student 4)

If it is a well-organized government, I can pay taxes. Taxes should be properly used and serve the welfare of taxpayers. That is, if the law is respected, the tax must be paid. Because in legislation, the welfare of the people is preferred. If there is a bribe, I do not want to pay taxes. (Student 5)

I agree to pay if justice is achieved. (Student 6)

I received a free education, so I have to pay taxes so that others can get an education like me. (Student 7)

To be honest, if the tax payment would be voluntary, I probably would not have paid. Regardless of how much income is received, people's needs are non-exhaustive, and as income grows, individual needs also increase, so I prefer to meet my own needs, 
rather than pay taxes. But if everyone thinks so, the government will not have the necessary resources to carry out its functions. Because it is known that taxes are the main income of the state. However, in the current situation, few people think about the activities of the state. Some people believe that this is not their problem; it is a problem of the state. (Student 8)

Revenues must be fairly distributed in order for our society to develop. Therefore, everyone must pay taxes on time and in full. (Student 9)

We need to think about our world. We must pay taxes so that the state can protect forests, rivers and the sea. (Student 10)

The state takes a tax and spends it on the necessary directions, eliminates certain gaps and shortcomings. Some people may say that they do not want to pay taxes because they will spend them on useful issues. For example, giving money to a family in need or educate anyone using this money. But these words will remain just a word. The key role of the state here is to force people to pay. People have to pay part of the income to the state because it is obligatory payment, on the other hand state should benefit from it in the most efficient way. (Student 11)

Thus, during the discussion, it turned out that the attitudes of most students towards taxation will be positive if their discontent disappears. This result is similar to the result of a study conducted by Sağlam (2013), which showed that if transparency of budget expenditures is ensured, taxpayer awareness will also increase.

\section{Conclusions and Recommendations}

This study clearly demonstrates the level and direction of the impact of education on tax attitudes, which are a reflection of tax ethics. The result showed that the research hypothesis was rejected. This result suggests that it is important to increase the tax ethics in society, giving education on the main issues of taxation, its functions and importance for students studying both in the field of economics and beyond. Implementation of "taxpayer training programs" for university students will have a positive impact on increasing tax ethics. In this context, it would be helpful to involve students in various social responsibility projects within the Ministry of Taxes and to ensure partnership between the Ministry of Taxes and universities.

Not only the Ministry of Taxes, but also various branches or institutions of the Ministry of Finance and the Ministry of Economy should support trainings to increase tax morale, and this should always be regulated by the state. For example, the Azerbaijan Export and Investment Promotion Foundation, Azerbaijan's Agency for the Development of Small and Medium-Sized Enterprises should be more active in this issue, and various non-governmental organizations should be encouraged with grants to increase taxpayer awareness of tax education importance. On the other hand, on the basis of students' answers, other suggestions can be made to reduce the students' negative attitude towards taxation. They are: 
- Implementation of financial amnesty. During this period, every citizen will declare their real wealth. After the financial amnesty, an annual income and assets declaration should be applied.

- Ensuring transparency and equal conditions in government procurement.

- Preparation and implementation of awareness raising activities (special courses at educational institutions, advertising companies, incentive and educational films, etc.) reflecting the importance of tax for the development of the economy and society as a whole.

There are some limitations in our study. To achieve high results, it would be useful to hold this questionnaire with a large number of students. It would also be good if the students had practical training in various financial institutions during the tax class period. Then we could observe and find more detailed information about the attitude of students towards taxation and identify suitable solutions to increase it.

\section{References}

[1]. Alm, J., Jackson, B.R., McKee, M. (1992). Institutional Uncertainty and Taxpayer Compliance, American Economic Review, 82, 1018-1026.

[2]. Alm, J., Kirchler, E., Muehlbacher, S. Gangl,K., Hofmann, E. Kogler, C., Pollai, M. (2012). Rethinking the Research Paradigms for Analyzing Tax Compliance Behaviour, https://www.researchgate.net/publication/266318170_Rethinking_the_research_paradigms_fo



[3]. Alm,J., Torgler, B. (2006). Culture Differences and Tax Morale in the United States and in Europe, Journal of Economic Psychology, 27(2), 224-246.

[4]. Beron, K.J., Tauchen, H.V., Witte, A.D. (1992). The Effect of Audits and Socioeconomic Variables on Compliance, In: Why People Pay Taxes: Tax Compliance and Enforcement, Ann Arbor: University of Michigan Pres., 67-89.

[5]. Besley,T., Persson,T. (2014). Why do developing countries tax so little?, Journal of Economic Perspectives, 28 (4), 99-120.

[6]. Carley, K.M., Maxwell, D.T. (2006). Understanding Taxpayer Behavior and Assessing Potential IRS Interventions Using Multiagent Dynamic-Network Simulation, Available online: http://www.casos.cs.cmu.edu/publications/papers/understandingtaxpayer-behavior.pdf (accessed on 09.04.2019).

[7]. Chan, C.W., Troutman, C.S., O'Bryan, D. (2000). An expanded model of taxpayer compliance: Empirical evidence from the United States and Hong Kong. Journal of International Accounting, Auditing and Taxation, 9(2), 83-103.

[8]. Chen, K., Lee, C., Tsai, H. (2019) Taxation of wealthy individuals, inequality governance and corporate social responsibility, Sustainability, 11, 1851; doi:10.3390/su11071851.

[9]. Çiçek,U., Bitlisli,F. (2017). Vergi eğitiminin üniversite öğrencilerinin vergi bilinci ve farkındalığı üzerindeki etkisi: bir araştırma, Muhasebe ve Vergi Uygulamaları Dergisi, 10 (2), 261-278

[10]. Doerrenberg, P., Peichl, A. (2017). Tax morale and the role of social norms and reciprocity: Evidence from a randomized survey experiment, ifo Working Papers, 242.

[11]. Dubin, J.A., Graetz, M.J., Wilde, L.L. (1990). The Effect of Audit Rates on the Federal Individual Income Tax: 1977-1986, National Tax Journal, 43(4), 395-409.

[12]. Eriksen, K., Fallan, L. (1996). Tax Knowledge and Attitudes Towards Taxation; A Report on a Quasi-Experiment, Journal of Economic Psychology. Vol. (17), 387-402. 
[13]. Fanea-Ivanovici, M., Muşetescu, R., Pană, M.;,Voicu, C. (2019). Fighting corruption and enhancing tax compliance through digitization: achieving sustainable development in Romania, Sustainability, 11, 1480; doi:10.3390/su11051480

[14]. Hashimzade, N., Myles, G.D., Tran-Nam, B. (2013). Applications of behavioural economics to tax evasion, Journal of Economic Surveys, 27, 941-77.

[15]. Ipek, S., Kaynar, I., (2009). Vergiye Gönüllü Uyum Konusunda Çanakkale İline Yönelik Amprik Bir Çalışma, Yönetim ve Ekonomi, 16 (1), 173-190.

[16]. James, S., Alley, C. (2002). Tax compliance, self assessment system and tax administration. Journal of Finance, and Management in Public Services, 2(2), 27-42.

[17]. Kalendiene, J.; Pukeliene,V. (2011). Taxation and Economic Sustainability, Working Papers, CIGE, 2011.

[18]. Kot, S., Štefko, R., Dobrovic,J., Rajnoha,R., Váchal, J. (2019). The main performance and effectiveness factors of sustainable financial administration reform using multidimensional statistical tools, Sustainability, 11, 3609; doi:10.3390/su11133609

[19]. Kwok, B.Y.S., Yip, R.W.Y. (2018). Is tax education good or evil for boosting tax, compliance? Evidence from Hong Kong, Asian Economic Journal, 32 (4), 359-386.

[20]. Lin, M.T., Carrol, C.F. (2000). The impact of tax knowledge on the perceptions of tax fairness and attitudes towards compliance, Asian Review of Accounting, 8, 44-58.

[21]. Loo, E.C., McKerchar, M., Hansford, A. (2009). Understanding the compliance behavior of Malaysian individual taxpayers using a mixed method approach. Journal of the Australasian Tax Teachers Association, 4 (1), 181-202.

[22]. McGee R.W. (2012). Education Level and the Ethics of Tax Evasion. In: McGee R. (eds.) The Ethics of Tax Evasion. Springer, New York, NY, 451-457.

[23]. McGee, R.W., Ross, A.M. (2012). Education level and ethical attitude toward tax evasion: A six-country study, Journal of Legal, Ethical and Regulatory Issues, 15(2), 93-138.

[24]. McGee, R.W. (1999). Is it unethical to evade taxes in an evil or corrupt state? A look at Jewish, Christian, Muslim, Mormon and Baha'i perspectives, Journal of Accounting, Ethics \& Public Policy, 2(1), 149-181.

[25]. Milliron, V. (1985). A Behavioral Study of the Meaning and Influence of Tax Complexity. Journal of Accounting Research, 23(2), 794-816.

[26]. Murphy, K. (2005). Regulating more effectively: The relationship between procedural justice, legitimacy, and tax non-compliance. Journal of Law and Society, 32, 562-589.

[27]. Ottoway, A.K.C. (1962). Education and Society: An Introduction to the Sociology of Education, London: Routledge.

[28]. Preobragenskaya, G. McGee, R.W. (2016). A Demographic Study of Russian Attitudes Toward Tax Evasion, Journal of Accounting, Ethics and Public Policy, 17(1), 137-207.

[29]. Sağlam, M. (2013). Vergi Algısı ve Vergi Bilinci Üzerine Bir Araştırma: İktisadi ve İdari Bilimler Fakültesi Öğrencilerinde Vergi Algısı ve Bilinci. Sosyoekonomi, 19(19), 315-334.

[30]. Teyyare, E., Kumbashl1, E. (2016). Vergi bilinci ve vergi ahlakının gelişmesinde maliye bölümü eğitiminin rolü, AİB̈̈ Sosyal Bilimler Enstitüsü Dergisi, 2016, 16(4), 1-29.

[31]. Torgler, B. (2003). Tax Morale: Theory and Empirical Analysis of Tax Compliance, Unpublished PhD. Thesis, Bazel: Universitat Basel, Available online: https://edoc.unibas.ch/56/1/DissB 6463.pdf (accessed on 12.03.2019).

[32]. Torgler, B. (2006). The importance of faith: Tax morale and religiosity, Journal of Economic Behavior \& Organization, 61(1), 81-109.

[33]. Torgler, B., Demir, I.C., Macintyre, A., Schaffner, M. (2008). Causes and Consequences of Tax Morale: An Empirical Investigation, Economic Analysis and Policy, 38(2), 313-339. 